\title{
Outpatient treatment of COVID-19 with ste- roids in the phase of mild pneumonia with- out the need for admission as an opportunity to modify the course of the disease: A structured summary of a rando- mised controlled trial
}

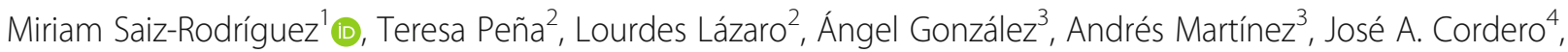
Juan T. Vicente ${ }^{5}$, Fernando Richard ${ }^{5}$, María Jesús Coma ${ }^{1}$, Martín de Frutos ${ }^{1}$, Jorge Labrador ${ }^{1,6}$ and Ana Pueyo ${ }^{2^{*}}$

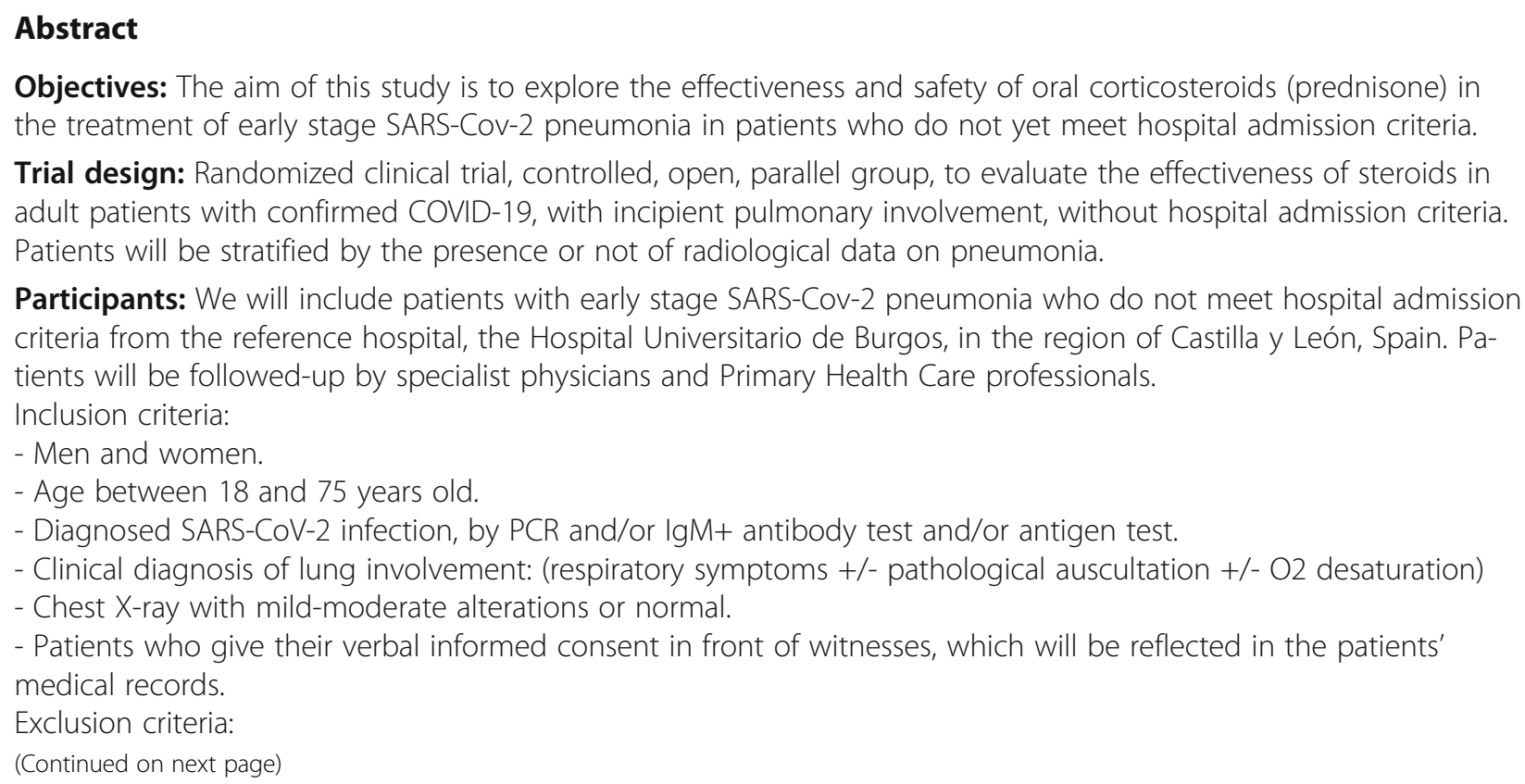

Objectives: The aim of this study is to explore the effectiveness and safety of oral corticosteroids (prednisone) in the treatment of early stage SARS-Cov-2 pneumonia in patients who do not yet meet hospital admission criteria.

Trial design: Randomized clinical trial, controlled, open, parallel group, to evaluate the effectiveness of steroids in adult patients with confirmed COVID-19, with incipient pulmonary involvement, without hospital admission criteria. Patients will be stratified by the presence or not of radiological data on pneumonia.

Participants: We will include patients with early stage SARS-Cov-2 pneumonia who do not meet hospital admission criteria from the reference hospital, the Hospital Universitario de Burgos, in the region of Castilla y León, Spain. Patients will be followed-up by specialist physicians and Primary Health Care professionals.

Inclusion criteria:

- Men and women.

- Age between 18 and 75 years old.

- Diagnosed SARS-CoV-2 infection, by PCR and/or IgM+ antibody test and/or antigen test.

- Clinical diagnosis of lung involvement: (respiratory symptoms +/- pathological auscultation +/- O2 desaturation) - Chest X-ray with mild-moderate alterations or normal.

- Patients who give their verbal informed consent in front of witnesses, which will be reflected in the patients' medical records.

Exclusion criteria:

(Continued on next page)

\footnotetext{
* Correspondence: pueyo@saludcastillayleon.es

${ }^{2}$ Neumology Department, Hospital Universitario de Burgos, Avda Islas Baleares, 3, Burgos, Spain

Full list of author information is available at the end of the article
}

(c) The Author(s). 2020 Open Access This article is licensed under a Creative Commons Attribution 4.0 International License, which permits use, sharing, adaptation, distribution and reproduction in any medium or format, as long as you give appropriate credit to the original author(s) and the source, provide a link to the Creative Commons licence, and indicate if changes were made. The images or other third party material in this article are included in the article's Creative Commons licence, unless indicated otherwise in a credit line to the material. If material is not included in the article's Creative Commons licence and your intended use is not permitted by statutory regulation or exceeds the permitted use, you will need to obtain permission directly from the copyright holder. To view a copy of this licence, visit http://creativecommons.org/licenses/by/4.0/ The Creative Commons Public Domain Dedication waiver (http://creativecommons.org/publicdomain/zero/1.0/) applies to the data made available in this article, unless otherwise stated in a credit line to the data. 
(Continued from previous page)

- Oxygen desaturation below 93\% or $\mathrm{PO}_{2}<62$.

- Moderate-severe dyspnea or significant respiratory or general deterioration that makes admission advisable.

- Chest X-ray with multifocal infiltrates.

- Insulin-dependent diabetes with poor control or glycaemia in the emergency room test greater than $300 \mathrm{mg} / \mathrm{ml}$

(fasting or not).

- Other significant comorbidities: Severe renal failure (creatinine clearance $<30 \mathrm{~mL} / \mathrm{min}$ ); cirrhosis or chronic liver

disease, poorly controlled hypertension.

- Heart rhythm disturbances (including prolonged QT).

- Severe immunosuppression (HIV infection, long-term use of immunosuppressive agents); cancer.

- Pregnant or breast-feeding women.

- Patients under use of glucocorticoids for other diseases.

- History of allergy or intolerance to any of the drugs in the study (prednisone, azithromycin or

hydroxychloroquine).

- Patients who took one or more of the study drugs in the 7 days prior to study inclusion.

- Patients taking non-suppressible drugs with risk of QT prolongation or significant interactions.

- Patients unwilling or unable to participate until study completion.

- Participation in another study.

Intervention and comparator: Eligible patients will be randomized to receive standard outpatient treatment only (group 1) or standard outpatient treatment plus prednisone (group 2).

- Group 1: paracetamol $1 \mathrm{~g} / 8 \mathrm{~h}$ (on demand) + hydroxychloroquine $400 \mathrm{mg} / 12 \mathrm{~h}$ the first day, $200 \mathrm{mg} / 12 \mathrm{~h}$ for 4 days + azithromycin $500 \mathrm{mg} / 24 \mathrm{~h}$ for 5 days.

- Group 2: paracetamol $1 \mathrm{~g} / 8 \mathrm{~h}$ (on demand) + hydroxychloroquine $400 \mathrm{mg} / 12 \mathrm{~h}$ the first day, $200 \mathrm{mg} / 12 \mathrm{~h}$ for 4 days + azithromycin 500 mg/24h for 5 days + prednisone 60 mg / 24 h for 3 days, 30 mg / 24 h for 3 days and 15 $\mathrm{mg} / 24 \mathrm{~h}$ for 3 days.

Main outcomes: If the patient requires ambulatory observation, according to the protocol established in this respect in the Emergency Department, meets all the criteria for inclusion and none for exclusion, data will be taken by the person responsible on the data collection sheet. The main result is admission after 30 days. Secondary outcomes are 30-day ICU admission and hospital stay. The safety variable will be the occurrence of clinical symptoms or delirium related to the steroids. Also, the possible decompensations of diabetes will be measured. All tests will be on an intention-to-treat basis.

Randomisation: Treatment will be assigned according to stratified randomization by the presence or absence of radiological data of lung involvement (previously performed by random sequence 1:1 generated with Epidat and kept hidden by opaque, sealed envelopes, which will only be opened after inclusion and basal measurement).

Blinding (masking): Participants, caregivers and personnel responsible for outcomes measurement will not be blinded to group assignment, once the patient is included and the basal measurement performed, as per protocol design.

Numbers to be randomised (sample size): The percentage of patients with incipient lung involvement is unknown, but given that pulmonary involvement already exists it is estimated to be around $20 \%$. We consider that the intervention could reduce this percentage to 5\%, so the necessary sample size would be 200 subjects (100 per group), with a power of $80 \%$ and an estimated loss percentage of $10 \%$.

Trial Status: The protocol with code TAC-COVID-19, version 2.0 on date: April 16, 2020 is approved by the Spanish Drug Agency (AEMPS) and the local Ethics Committee. The trial is in the recruitment phase. Recruitment began 19 April, 2020 and is anticipated to be complete by April 2021.

Trial registration: The trial was registered under the title "OUTPATIENT TREATMENT OF EARLY PULMONARY COVID19 WITH CORTICOSTEROIDS AS AN OPPORTUNITY TO MODIFY THE COURSE OF THE DISEASE" with EUdraCT number 2020-001622-64, registered on 3 April 2020.

(Continued on next page) 
(Continued from previous page)

Full protocol: The full protocol is attached as an additional file, accessible from the Trials website (Additional file 1). In the interest in expediting dissemination of this material, the familiar formatting has been eliminated; this Letter serves as a summary of the key elements of the full protocol.

Keywords: COVID-19, Randomised controlled trial, Protocol, Early pulmonary, Prednisone, Outpatients

\section{Supplementary information}

Supplementary information accompanies this paper at https://doi.org/10. 1186/s13063-020-04575-w

Additional file 1. Full Study Protocol.

\section{Acknowledgements}

Not applicable.

\section{Authors' contributions}

MSR and AP wrote the manuscript. TP, LL, AG, AM, JAC, JTV, FR, MJC, MF, JL and AP designed the research. The author(s) read and approved the final manuscript.

\section{Funding}

There is no funder for this study. There has been no involvement of funding sources in the study design; in the collection, analysis and interpretation of data; in the writing of this manuscript; or in the decision to submit the article for publication.

\section{Availability of data and materials}

The data will be available from the author on reasonable request. Please contact the corresponding author Dra. Ana Pueyo

(apueyo@saludcastillayleon.es).

\section{Ethics approval and consent to participate}

The protocol was evaluated by the Local Research Ethics Committee of Burgos, Spain, on April 17, 2020 with the reference code TAC-COVID-19 and number 2295. It was approved on April 17, 2020.

Patients will be asked for their verbal informed consent with the presence of witnesses, and this will be reflected in the medical record before included in the clinical trial.

\section{Consent for publication}

Not applicable.

\section{Competing interests}

The authors declare that they have no competing interests.

\section{Author details}

${ }^{1}$ Research Unit, Hospital Universitario de Burgos, Burgos, Spain. ${ }^{2}$ Neumology Department, Hospital Universitario de Burgos, Avda Islas Baleares, 3, Burgos, Spain. ${ }^{3}$ Gerencia de Atención Primaria de Burgos, Burgos, Spain. ${ }^{4}$ Instituto de Investigación Sanitaria Bioaraba, Vitoria-Gasteiz, Álava, Spain. ${ }^{5}$ Emergency Department, Hospital Universitario de Burgos, Burgos, Spain. ${ }^{6}$ Hematology Department, Hospital Universitario de Burgos, Burgos, Spain.

Received: 26 June 2020 Accepted: 2 July 2020

Published online: 09 July 2020

\section{Publisher's Note}

Springer Nature remains neutral with regard to jurisdictional claims in published maps and institutional affiliations.

Ready to submit your research? Choose BMC and benefit from:

- fast, convenient online submission

- thorough peer review by experienced researchers in your field

- rapid publication on acceptance

- support for research data, including large and complex data types

- gold Open Access which fosters wider collaboration and increased citations

- maximum visibility for your research: over $100 \mathrm{M}$ website views per year

At $\mathrm{BMC}$, research is always in progress.

Learn more biomedcentral.com/submission 